\title{
Получение трансгенных линий мышей для изучения возможности конверсии лактозы в галактоолигосахариды в молочной железе
}

\author{
А.В. Смирнов , А.Н. Кораблев, А.М. Юнусова, Т.А. Шнайдер, И.А. Серова
}

\begin{abstract}
Аннотация: Современные методы трансгенеза позволяют проводить сложные модификации геномов животных для различных задач. В биотехнологии создают трансгенных животных с модификациями молока, в том числе с улучшенными антибактериальными свойствами, измененным липидным составом или новыми вкусовыми качествами. Одним из перспективных направлений в этой области можно назвать оверэкспрессию $\beta$-галактозидаз - ферментов, разлагающих лактозу, - для удаления лактозы из молока сельскохозяйственных животных. В нашей работе мы исследуем подход с экспрессией трансгалактазилирующего фермента молочнокислой бактерии Lactobacillus delbrueckii. В теории синтез этого фермента в молочной железе мыши должен приводить к исчезновению в молоке лактозы благодаря ее конверсии в галактоолигосахариды. Мы создали две трансгенные линии животных для тестирования этой гипотезы. На первом этапе протестировали различные варианты генетических конструкций, включая сигналы локализации в аппарат Гольджи, и выбрали два варианта гена $\beta$-галактозидазы под конститутивным и казеиновым промоторами для получения трансгенных линий мышей методом пронуклеарной микроинъекции. Для каждой из конструкций было получено по четыре трансгенных фаундера. Мы провели предварительный анализ характеристик трансгенных линий (копийность трансгена, экспрессия, наследование трансгена) и собрали молоко от лактирующих самок для дальнейших исследований.
\end{abstract}

Ключевые слова: трансгенез; молоко; лактоза; галактоолигосахариды; аппарат Гольджи.

Благодарности: Работа выполнена при финансовой поддержке РФФИ в рамках реализации проекта № 20-316-80001. Авторы выражают благодарность ЦКП микроскопии анализа биологических объектов ИЦиГ СО РАН.

Для цитирования: Смирнов А.В., Кораблев А.Н., Юнусова А.М., Шнайдер Т.А., Серова И.А. Получение трансгенных линий мышей для изучения возможности конверсии лактозы в галактоолигосахариды в молочной железе. Письма в Вавиловский журнал генетики и селекции. 2021;7(4):176-193. DOI 10.18699/LettersVJ2021-7-23

Original article

\section{Generating transgenic mice for investigating direct lactose conversion into galactooligosaccharides in mammary gland}

\author{
A.V. Smirnov凶, A.N. Korablev, A.M. Yunusova, T.A. Shnaider, I.A. Serova
}

\begin{abstract}
Present day transgenesis tools make it possible to carry out quite complex modifications of animal genomes for different goals. In biotechnology, transgenic animals are generated to modify the composition of milk, including antibacterial properties, lipid composition, or flavor. One of the promising directions in this area is the overexpression of $\beta$-galactosidases, enzymes that hydrolyze lactose, to remove this disaccharide from the milk of farm animals. In our work, we investigate an approach with the expression of the transgalactasylating enzyme of the lactic acid bacterium Lactobacillus delbrueckii. In theory, the synthesis of this enzyme in the mouse mammary gland should lead to the disappearance of lactose from milk, due to its conversion into galactooligosaccharides. We created two transgenic animal lines to test this hypothesis. At the first stage, we tested variants of genetic constructs, including Golgi localization signals, and selected two variants of the $\beta$-galactosidase transgene under the constitutive and casein promoters to obtain transgenic mouse strains by pronuclear microinjection. For each of the constructs, four transgenic founders were obtained. We carried
\end{abstract}

Федеральный исследовательский центр Институт цитологии и генетики Сибирского отделения Российской академии наук, Новосибирск, Россия Institute of Cytology and Genetics of the Siberian Branch of the Russian Academy of Sciences, Novosibirsk, Russia

凶hldn89@gmail.com

() Смирнов А.В., Кораблев А.Н., Юнусова А.М., Шнайдер Т.А., Серова И.А., 2021 
out a preliminary analysis of the characteristics of transgenic lines (transgene copy number, expression, inheritance of the transgene) and collected milk from lactating females for further research.

Key words: transgenesis; milk; lactose; galactooligosaccharides; Golgi apparatus.

For citation: Smirnov A.V., Korablev A.N., Yunusova A.M., Shnaider T.A., Serova I.A. Generating transgenic mice for investigating direct lactose conversion into galactooligosaccharides in mammary gland. Pisma v Vavilovskii Zhurnal Genetiki S Selektsii = Letters to Vavilov Journal of Genetics and Breeding. 2021;7(4):196-193. DOI 10.18699/LettersVJ2021-7-23 (in Russian)

\section{Введение}

Современный уровень развития биотехнологии и методов редактирования генома уже сейчас позволяет изменять свойства молока сельскохозяйственных животных - коров, коз, кроликов (Shepelev et al., 2018; Kalds et al., 2019), например, для улучшения его антимикробных свойств (Cooper et al., 2015), липидного (Wang et al., 2015) или белкового coстава (Laible et al., 2016). Трансгенез животных изучают также с целью превращения молочной железы в биореактор ценных рекомбинантных белков человека (Shepelev et al., 2018), в том числе и в нашей лаборатории (Serova et al., 2012; Burkov et al., 2013). Одним из перспективных направлений биотехнологических исследований является создание животных с безлактозным молоком.

Молоко почти всех животных содержит большое количество дисахарида лактозы, который составляет примерно 30 \% калорий молока. За гидролиз лактозы на глюкозу и галактозу отвечает фермента лактаза (Arribas et al., 2000). Известно, что уровень экспрессии этого фермента падает с возрастом у всех млекопитающих, включая человека, что приводит к синдрому «лактазная недостаточность» и затрудняет усвоение лактозы (Fassio et al., 2018). В некоторых человеческих популяциях произошли регуляторные мутации, активирующие экспрессию лактозы в течение все жизни (Fang et al., 2012; Ségurel, Bon, 2017). Благодаря своей полезности эти мутации были поддержаны отбором, однако за относительно недолгий срок (около 3-6 тыс. лет) они еще не успели широко распространиться. В настоящий момент больше половины всех людей страдают от лактазной недостаточности во взрослом состоянии (Ingram et al., 2009), что выражается в нарушениях пищеварения при употреблении молока.

За синтез и гидролиз лактозы отвечают соответственно ферменты лактоз-синтаза и лактаза. Лактоз-синтаза имеет полное название $\beta$-1,4-галактозилтрансфераза ( $\beta 4 \mathrm{Gal}-\mathrm{T} 1$ ) и относится к семейству галактозилтрансфераз (Gal-T) (EC 2.4.1.22). В обычных условиях лактоз-синтаза $\beta 4 \mathrm{Gal-T1}$ катализирует перенос моносахарида галактозы от UDPгалактозы на акцепторные молекулы: гликолипиды, пептидогликаны, гликопептиды - в аппарате Гольджи (Gabius, 2018). Эти модификации (N-гликозилирование) регулируют многие биологические процессы, включая внутриклеточный транспорт, межклеточные взаимодействия, синтез антител, фолдинг белков, формирование внеклеточного матрикса (Mihov, Spiess, 2015; Tannous et al., 2015; Gulati, Poluri, 2016). В период же лактации $\beta 4 \mathrm{Gal}-\mathrm{T} 1$ формирует лактоз-синтазный комплекс с белком-кофактором а-лактальбумином (LALBA) в молочной железе (Neville, 2009). Это приводит к изменению субстрат-специфичности $\beta 4 \mathrm{Gal}-\mathrm{T} 1$ и присоеди- нению галактозы к глюкозе с образованием дисахарида лактозы. Лактаза относится к ферментам класса $\beta$-галактозидаз (lactase/phlorizin hydrolase) (EC 3.2.1.23), которые катализируют отщепление концевых галактозных остатков от сахарных остовов различной длины (Liu et al., 2017). Лактаза расщепляет гликозидную $\beta-1,4$ связь, образованную лактозсинтазой. У млекопитающих лактаза локализуется на клеточной мембране эпителия кишечника.

Знания о молекулярных механизмах синтеза и гидролиза лактозы могут быть использованы для создания трансгенных линий животных с измененным составом молока. Мы решили оценить перспективы такого подхода, создав трансгенных мышей с экспрессией бактериального гена, превращающего лактозу в галактоолигосахариды (ГОС) (Nguyen et al., 2012), так как этот вариант модификации молока относительно прост с точки зрения белковой инженерии и в то же время очень актуален для молочной индустрии (Vera et al., 2016; Xiao et al., 2019). Современные промышленные способы получения безлактозного молока основаны на обработке молока-сырья $\beta$-галактозидазой (лактазой) для удаления лактозы. Для того чтобы получить ГОС, используют $\beta$-галактозидазы с высокой трансгалактозилазной активностью (Xiao et al., 2019). Это означает, что они катализируют перенос остатка галактозы на лактозу (Saqib et al., 2017). Этот процесс приводит к замещению в молоке лактозы на другие сахара, включая олигосахариды, состоящие из 3-6 остатков галактозы. Галактоолигосахариды стимулируют полезную микрофлору кишечника и обладают сладким вкусом, поэтому молоко и молочные продукты с ГОС имеют высокую пищевую ценность.

\section{Материал и методы}

Клонирование генетических конструкций

Ген LacZ* (GenelD: 4085367) был синтезирован в компании Cloning Facility (Россия) вместе с перекрывающимися плечами 20 п.о. для клонирования в реакции Гибсона. Фрагмент был смешан с остальными ПЦР-фрагментами: геном Clover (Addgene \#40259), НА-тагом и бэкбоном плазмиды pCAGGSmCherry (EcoRl/Bglll). Все фрагменты объединялись в одной реакции в соотношении 1:1:1:1. Фрагменты сигнальных пептидов клонировались в сайт EcoRI плазмиды pCAGGS-Cherry (Addgene \#41583) методом Гибсона (NEBuilder ${ }^{\oplus} \mathrm{HiFi}$ DNA Assembly Master Mix (NEB \#Е2621)). Для этого ПЦР-продукты, амплифицированные с кДНК мыши, смешивали с линеаризованной плазмидой в соотношении 1:1 в 10 мкл микса. Для получения конструкции LacZ* без Clover исходную плазмиду обрабатывали Agel, очищали через гель и религировали по липким концам. Клонирование конструкции LacZ* c казеиновыми регуляторными элементами, использованной 
для микроинъекций, было выполнено на основе вектора pGoatcasGMCSF, опубликованного ранее (Burkov et al., 2013).

\section{Тестирование конструкций на клетках}

Колокализацию флуоресцентного сигнала анализировали на клетках двух типов: НЕК293Т и первичных фибробластах мыши (линия OG2). В обоих случаях клетки трансфецировались липофектамином 3000 (Thermo Fisher Scientific) и свечение плазмид детектировалось после 48 ч на микроскопе ZOE Fluorescent Cell Imager (BioRad) или конфокальном микроскопе LSM 780 NLO (Zeiss).

Для иммунофлуоресцентного окрашивания первичные фибробласты мыши (линия OG2) были посажены на стекла

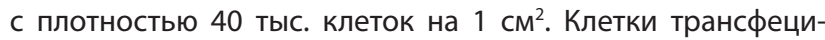
ровались различными вариантами плазмид mCherry-HA с помощью реагента TransFast ${ }^{\mathrm{TM}}$ (Promega). Через 30 ч после трансфекции клетки были зафиксированы в 4 \% параформальдегиде. После промывки 1× PBS клетки инкубировали в блокирующем растворе: 2 \% BSA (Sigma Aldrich), 0.2 \% Triton X-100 (Amresco), 5 \% FBS (Capricorn Scientific). Затем проводили окрашивание первичными антителами на НА-таг (1:1000) (\# 26183, Thermo Fisher Scientific) и Golgin-97 (1:1000) (\# PA5-30048, Thermo Fisher Scientific) в течение 5 ч на орбитальном шейкере. После этого клетки трижды промывали $1 \times$ PBS и затем окрашивали вторичными антителами (1:1000) (\#A21235, \#A11034, Thermo Fisher Scientific). Иммунофлуоресценцию детектировали на конфокальном микроскопе LSM 780 NLO (Zeiss).

Для проведения Вестерн блоттинга клетки HEK293 были трансфецированы шестью плазмидами LacZ* на 6w-плашке и собирались без сортировки на второй день после трансфекции (эффективность трансфекции 10-20\%). Осадок из нескольких миллионов клеток ресуспендировался в RIPA буфере (50 мM Tris- $\mathrm{HCl}$ pH 8, 150 мM NaCl, 1 \% Triton X100, $0.5 \%$ sodium deoxycholate, $0.1 \%$ SDS) и озвучивался для разрушения клеток. Концентрацию тотального белка в лизате оценивали китом Pierce ${ }^{\text {TM }}$ BCA Protein Assay Kit (Thermo Fisher Scientific). На белковый SDS-PAGE форез наносили по 15 мкг тотального белка для каждого образца. Белки разгоняли в 10 \% геле и переносили на PVDF мембрану. Мембрану сначала обратимо окрашивали для детекции тотального белка (Pierce ${ }^{\text {TM }}$ Reversible Protein Stain Kit for PVDF Membranes (Thermo Fisher Scientific)), а затем последовательно инкубировали с первичными антителами на НА-таг (\# 26183, Thermo Fisher Scientific) (1:1000) (ночь при $\left.4^{\circ} \mathrm{C}\right)$ и вторичными антителами с пероксидазой хрена (HRP) (1:1000) (sc-2357 SCBT) в течение 2 ч при $25^{\circ} \mathrm{C}$. Результаты Вестерн блоттинга анализировали китом ECL substrate solution (Millipore) на приборе Chemidoc XRS Imaging system (Bio-Rad).

Для анализа $\beta$-галактозидазной активности методом X-gal трансфецированные НЕК293 фиксировали 4 \% параформальдегидом, промывали $1 \times$ PBS и инкубировали в среде с X-gal (1 мг/мл) в течение 16 ч при температуре $37^{\circ} \mathrm{C}$.

Пронуклеарные микроинъекции

и детекция трансгенных животных

Обе конструкции были вырезаны из плазмидных бэкбонов по соответствующим сайтам рестрикции (рис. 1) и очищены выделением из агарозного геля и на магнитных частицах
AMPure XP (Beckman Coulter \#А63880). Для инъекций ДНК разводили в ТЕ-буфере до концентрации 10 нг/мкл. Это соответствует примерно 1000-2000 копий трансгена на один пронуклеус. Раствор инъецировали в пронуклеусы зигот (C57BL/6 генотип) с помощью прибора Transjector 5246 (Eppendorf). Зиготы культивировали 1 ч в среде М16 на $37^{\circ} \mathrm{C}$ при $5 \% \mathrm{CO}_{2}$. Выжившие зиготы подсаживали в яйцеводы псевдобеременным самкам CD-1.

Геномную ДНК выделяли методом фенол-хлороформной экстракции из кончика хвоста. Генотипирование проводили с помощью кита HS-Taq (+MgCl2) (Биолабмикс) и праймеров на ген LacZ* (AAGAGGAGCAATATCAATGCCGT, CTGTCCGGTCTGCAAACACGAG) (5'-3').

Работа по получению трансгенныхживотных была выполнена на базе SPF-вивария ИЦиГ СО РАH (RFMEFI61914Х0005, RFMEFI61914Х0010). Все эксперименты были одобрены этическим комитетом по защите животных ИЦиГ СО РАН в соответствии с документами и рекомендациями Министерства здравоохранения РФ (2010/708n/RF), NRC и FELASA.

Определение копийности с помощью

капельной цифровой ПцР (ddPCR)

Чтобы определить копийность встроек трансгенов у животных, мы использовали цифровую ПЦР на базе кита ddPCR Supermix for Probes (No dUTP) и прибора QX100 ddPCR Systems (Bio-Rad) по рекомендациям производителя. Одна 20 мкл реакция содержала 1× ddPCR Supermix, 900 нМ праймеров, 250 нМ зондов и 20 нг геномной ДНК, обработанной рестриктазой Hindlll. Копийность трансгена LacZ* расчитывали на основе референсного гена Emid1 (одна копия в гаплоидном геноме). Цифровую ПЦР проводили по следующей программе: $95^{\circ} \mathrm{C}$ в течение 10 мин, затем 40 циклов из $95{ }^{\circ} \mathrm{C}-30$ с и $55^{\circ} \mathrm{C}-1$ мин; с финальным шагом $98{ }^{\circ} \mathrm{C}-7$ мин и $20{ }^{\circ} \mathrm{C}-30$ мин. Все шаги имели скорость нагрева $2{ }^{\circ} \mathrm{C} / \mathrm{c}$. Данные анализировали, используя программу QuantaSoft (Bio-Rad, USA). Последовательности праймеров и зондов (5'-3'): Emid1 (GCCAGGACTGGGTAGCAC, AGGAGGCTCCTGAATTTGTGACAAG, FAM-CCTGGGTCATCTGAGCTGAGTCC-BHQ1), LaCZ* (GATCTGGCGGCCTATACAGCCT, CTGTCCGGTCTGCAAACACGAG, HEX-CGGCCCACAGACTACGAGTTCTGCGG-BHQ2).

\section{Анализ экспрессии с помощью ОТ-ПЦР и ddPCR}

Для выделения РНК органы помещали в 2 мл пробирки с 1 г керамических частиц Lysing Matrix A (MP Biomedicals) и 500 мкл TRI Reagent (Sigma-Aldrich). Гомогенизацию органов проводили с помощью прибора SuperFastPrep-2 ${ }^{\text {тм }}$ (MP Biomedicals). Далее РНК выделяли в соответствии с протоколом производителя TRI Reagent (Sigma-Aldrich). Перед проведением обратной транскрипции (ОТ) РНК обрабатывали ДНКазой I (Thermo Fisher Scientific). Обратную транскрипцию осуществляли китом RevertAid RT (Thermo Fisher Scientific) с использованием 500 нг РНК на 20 мкл реакции и случайными праймерами. ОТ-ПЦР анализ проводили с 0.5 мкл реакции обратной транскрипции и праймерами на ген LacZ* (GATCTGGCGGCCTATACAGCCT, CTGTCCGGTCTGCAAACACGAG) и ген Rpl4 (GGCTGCTTCCCTCAAGAGTA, AATCTTCTTGCGTGGTGCTC) (5'-3'). Для оценки экспрессии LacZ* методом капельной цифровой ПЦР 
a Контрольные плазмиды
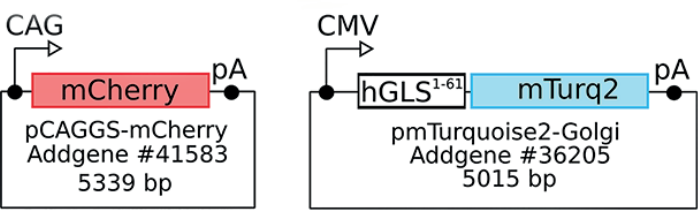

6 Конструкции для теста сигнала локализации

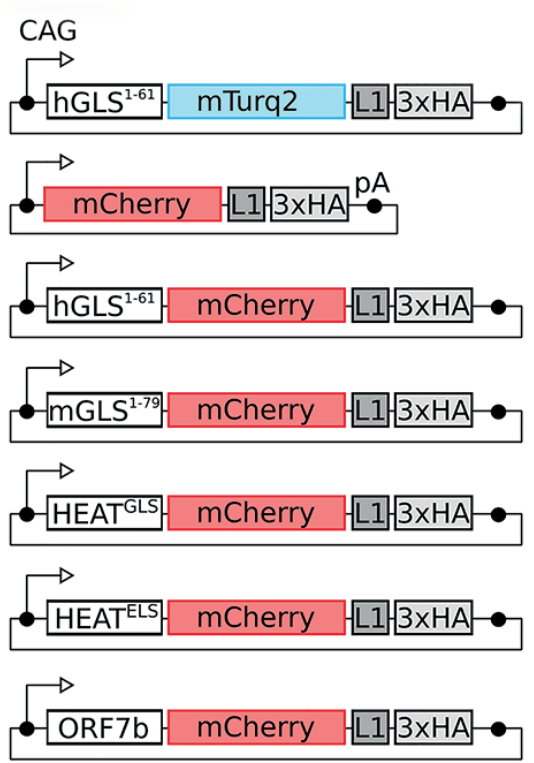
Конструкции для тестов LacZ*
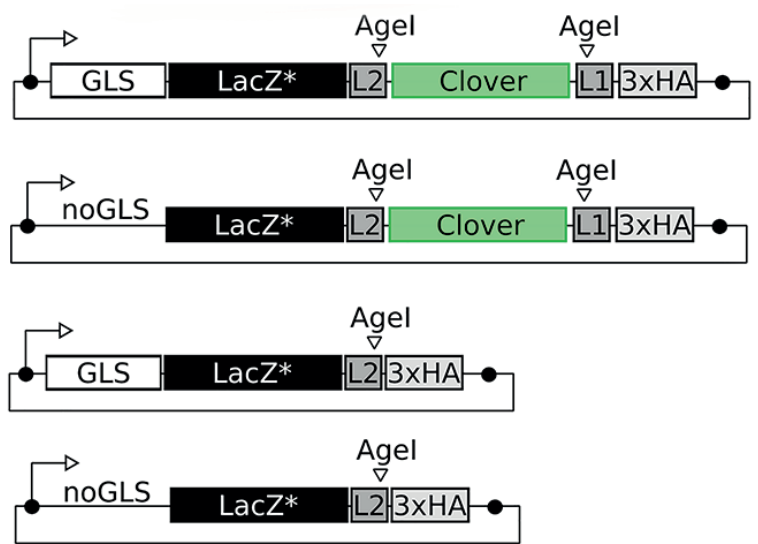

2
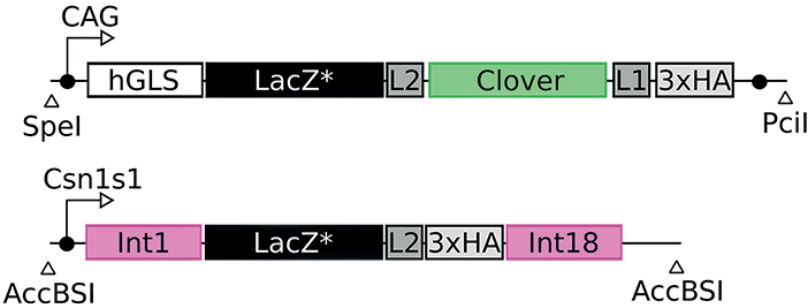

\section{[L1]=TGGGSGG L2 $=$ TGTSGSETPGTSTSESATPES}

Рис. 1. Схема генетических конструкций, использованных в работе: $a$ - конструкции были созданы на основе плазмиды pCAGGS-mCherry и pmTurquoise2-Golgi; 6 - плазмиды для анализа функций сигналов локализации в АГ. Сверху контрольная плазмида, которая маркирует АГ (mTurq2). Ниже - изучаемые сигнальные пептиды, слитые с белком Cherry. L1, L2 - пептидные линкеры и их последовательности; в - дополнительная проверка выбранных сигналов локализации в АГ (mGLS, hGLS) в составе белка LacZ*; г две конструкции LacZ*, подготовленные для пронуклеарных микроинъекций. Конструкция CAG-hGLS-LacZ*-Clover-HA. Ген LacZ* слит с сигналом локализации в AГ hGLS, геном Clover и HA-тагом для детекции антителами. Экспрессия идет с сильного промотора САG. Трансген вырезан из плазмиды по сайтам Spel и Pcil. Размер итогового фрагмента 6204 п.о. Конструкция Csn1s1-mGLS-LacZ*-HA: ген LacZ* слит с сигналом локализации в AГ mGLS и HA-тагом без гена Clover. Экспрессия идет с «молочного» промотора гена Csn1s1 козы. Розовые прямоугольники - регуляторные интроны Csn1s1 из козы и быка. Трансген вырезан из плазмиды по сайтам АсcBSI. Размер итогового фрагмента 8550 п.о.

(ddPCR) применяли тот же протокол, что и для подсчета копийности. Отличием было то, что использовали кДНК (0.5 мкл на реакцию) и другой референсный ген (Rpl4). Последовательности праймеров и зондов (5'-3'): Rpl4 (GGCTGCTTCCCTCAAGAGTA, AATCTTCTTGCGTGGTGCTC, FAMAGCCCAGAAATCCAAAGAGCCCTCC-BHQ1), LaCZ* (GATCTGGCGGCCTATACAGCCT, CTGTCCGGTCTGCAAACACGAG, HEX-CGGCCCACAGACTACGAGTTCTGCGG-BHQ2).

\section{Результаты}

Клонирование генетических конструкций

В качестве ГОС-синтезирующей $\beta$-галактозидазы мы выбрали один из охарактеризованных ранее ферментов с высокой трансгалактозилазной активностью. Это ген из бактерии Lactobacillus delbrueckii subsp. bulgaricus DSM 20081 (GenelD: 4085367) (Nguyen et al., 2012). Далее в тексте этот ген обозначен как LacZ*, чтобы избежать возможной путаницы с геном Escherichia coli, часто используемым в биологических экспериментах. In vitro в оптимальных условиях он способен конвертировать более 90 \% лактозы в ГОС и моносахариды (Nguyen et al., 2012). Ген LacZ* длиной 3024 пар оснований был синтезирован и кодоноптимизирован для экспрессии в клетках мышей и встроен в плазмиду рCAGGS (Gurtan et al., 2012).

Синтез многих компонентов молока, включая и лактозу, происходит в аппарате Гольджи (АГ) с последующей секрецией в просвет протока молочной железы, поэтому для оптимальной активности фермента LacZ* необходимо обеспечить его локализацию в аппарате Гольджи. Мы протестировали сигналы локализации белков в АГ, соединив их с флуоресцентным белком mCherry (см. рис. 1, a, б). Нами были выбраны известные ранее домены различных белков: фрагмент $\beta$-1,4-галактозилтрансферазы 1 (B4GALT1) мыши (1-79 а.к.) ("mGLS"); фрагменты mTOR мыши, содержащие 


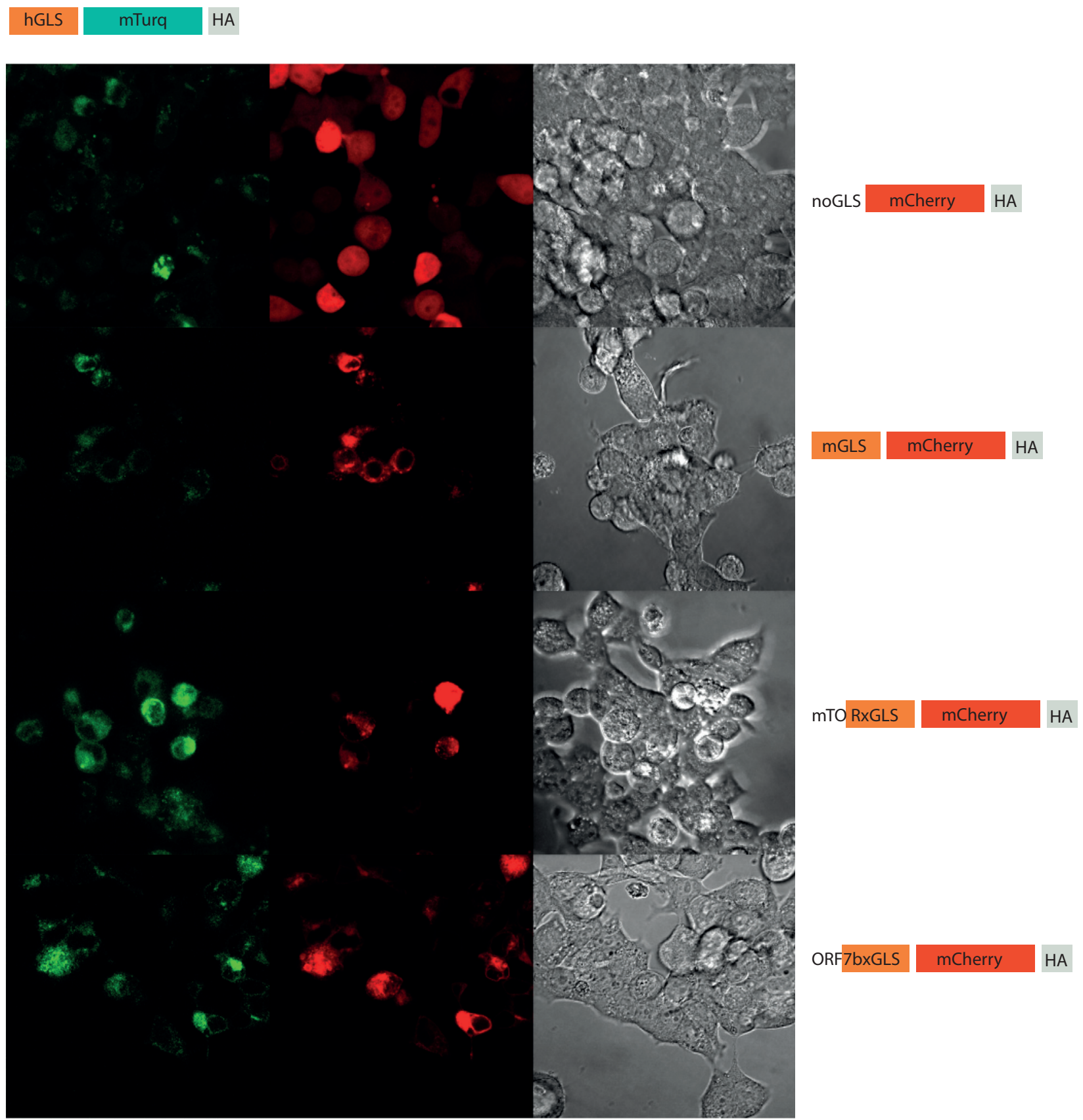

Рис. 2. Тестирование сигналов локализации в аппарате Гольджи в клетках HEK293. hGLS-mTurq-HA - контрольная плазмида для маркирования АГ; noGLS - вариант без сигнала локализации (белок распределен по всей клетке); mGLS, mTORxGLS, ORF7bxGLS - альтернативные варианты сигнала локализации в аппарате Гольджи

HEAT-повторы (931-1039 и 941-1039 а.к.) ("mTORxGLS", "mTORxELS"); фрагмент SARS-CoV ORF7b (9-30 а.к.) ("ORF7bxGLS"). Эти фрагменты были ПЦР-амплифицированы с кДНК мыши или синтезированы олигами (ORF7b). Итоговые конструкции клонировали на базе плазмиды pCAGGS-Cherry с помощью метода Гибсона. Для контроля использовали плазмидную конструкцию hGLS-mTurq-HA, на основе плазмиды pmTurquoise2-Golgi, заказанной с Addgene (\#36205) (см. рис. 1, a), и также перенесенную в плазмиду pCAGGS. Контрольная плазмида кодирует флуоресцентный белок mTurquoise (зеленоватое свечение), слитый с сигналом локализации в АГ из B4GALT1 человека (1-61 а.к.) (Goedhart et al., 2012). Во всех конструкциях присутствует НА-таг на С-конце для детекции белков.

Синтезированный ген LaCZ* был дополнительно модифицирован. К нему добавили различные сигналы локализации, а также ген Clover для детекции в клетках и тканях животных (см. рис. 1, в). Так как линкерные последовательности плазмид включали сайты рестрикции Agel, мы могли получить укороченный вариант конструк- 
$a$
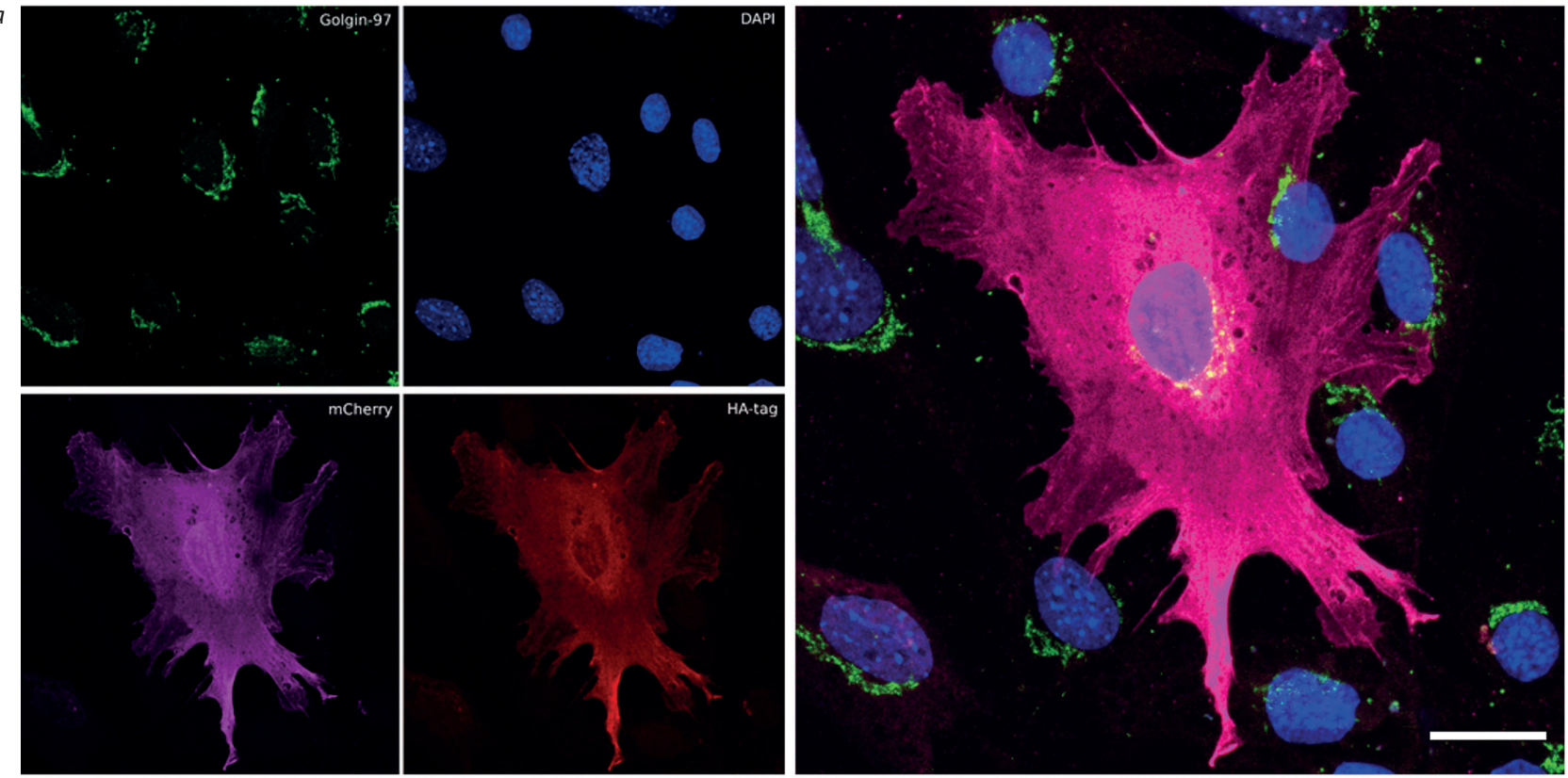

hGLS

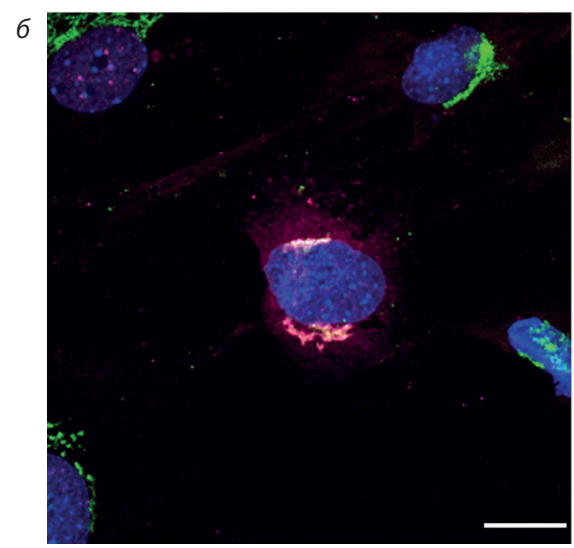

mTOR-ELS

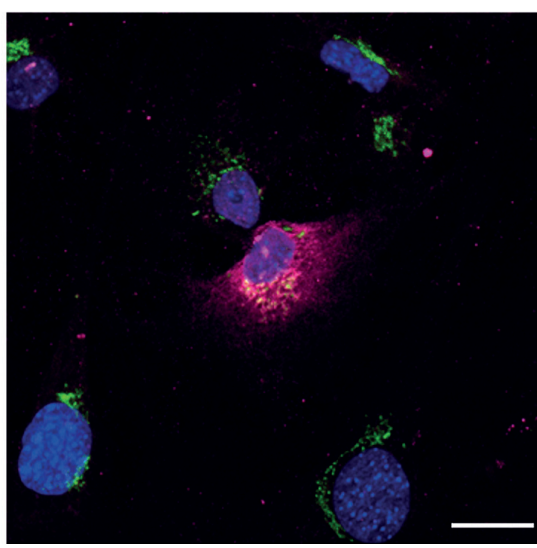

ORF7b

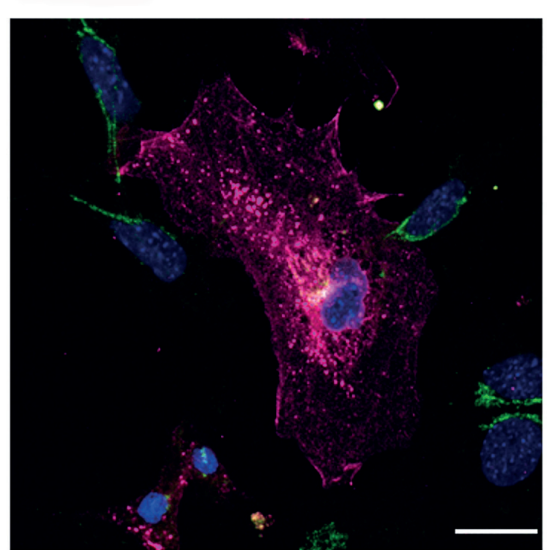

Рис. 3. Иммунофлуоресцентный анализ таргетирования белка mCherry в АГ фибробластов мыши: $a$ - клетки, трансфецированные плазмидой mCherry без сигнала локализации. Зеленый сигнал - антитела на Golgin-97, маркер транс-отдела АГ. Розовый сигнал - флуоресценция mCherry. Красный сигнал - НА-таг. Синий сигнал - DAPI; б - варианты сигналов локализации. Масштабный отрезок - 20 мкм

ции без Clover в одну стадию. Подготовленные конструкции (варианты mCherry и LacZ*) были предварительно протестированы в культурах клеток.

Тестирование генетических конструкций на клетках Мы поставили плазмидные трансфекции на клетках человека НЕK293 (рис. 2, 1П и 2П) и фибробластах мыши (рис. 3П) и проанализировали свечение флуоресцентных белков. Как видно на рис. 2, контрольный зеленый белок mTurquoise с сигналом hGLS локализуется в небольшие клампы и гранулы рядом с ядром, что соответствует расположению аппарата Гольджи. Красный белок mCherry без сигналов GLS распределен по всей цитоплазме клетки (см. рис. 2, верх). Белок mCherry с мышиным сигналом локализации mGLS (см. рис. 2) всегда локализовался вместе с контрольным сигналом hGLS, из чего можно заключить, что они имеют идентичные свойства. Сигналы из mTOR (mTORxGLS и mTORxELS) и из вирусного белка ORF7b показали в целом похожую на
hGLS картину колокализации, однако их колокализация с mTurq была однозначной не во всех клетках. Плазмиды с LacZ* также демонстрировали схожий паттерн (см. рис. 1П и 2П).

Мы также протестировали таргетирование белков в АГ с использованием антител на НA-таг и Golgin-97, белок-маркер транс-отдела аппарата Гольджи. Иммунофлуоресцентный анализ трансфецированных первичных фибробластов мыши методом конфокальной микроскопии позволил с высокой точностью локализовать белки. Как видно на рис. 3, $a$, белок mCherry без сигнала локализации распределен по всей цитоплазме клетки, а при наличии определенных сигналов таргетируется в различные компартменты (см. рис. 3, б). Важно, что hGLS-mCherry идеально колокализуется с транс-отделом аппарата Гольджи. Для дальнейшей работы вариации этого сигнала (hGLS, mGLS) были присоединены к гену LacZ* (см. рис. 1, в). 


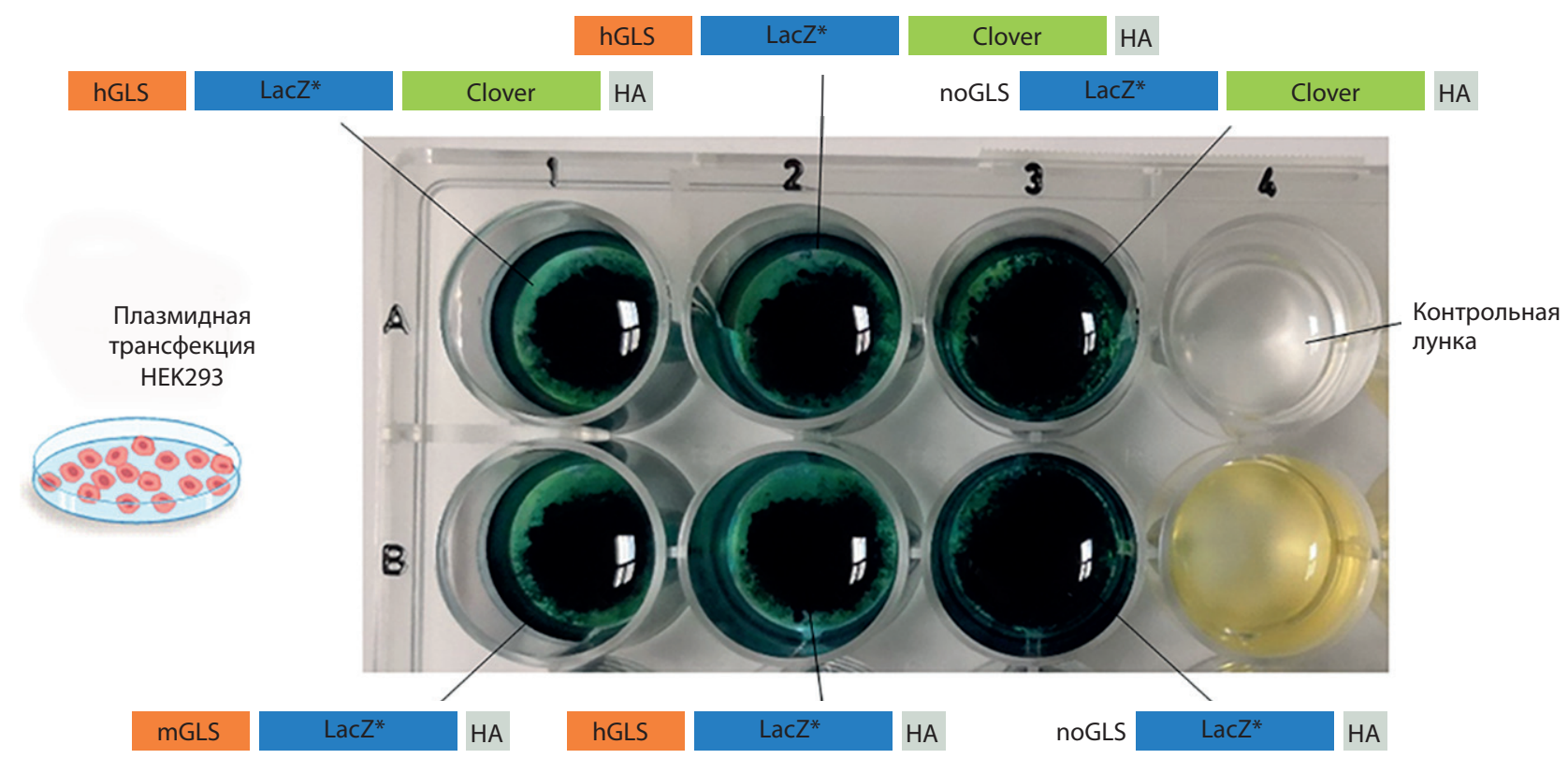

Рис. 4. Тестирование $\beta$-галактозидазной активности фермента LacZ* в клетках. Субстрат X-gal разлагается ферментами на галактозу и 5-бромо-4-хлоро-3-гидроксииндол. Последний димеризуется при окислении на воздухе с образованием нерастворимого вещества синего цвета. Клетки HEK293, экспрессирующие конструкции c LacZ*, инкубировали c X-gal. Контрольная лунка содержала клетки без трансфекции

Эффективность получения трансгенных животных методом пронуклеарной микроинъекции

\begin{tabular}{lllll} 
Конструкция & Вымыто зигот & $\begin{array}{l}\text { Подсажено } \\
\text { зигот }\end{array}$ & $\begin{array}{l}\text { Реципиентные } \\
\text { самки (беременность) }\end{array}$ & $\begin{array}{l}\text { Родилось } \\
\text { (трансгенные) }\end{array}$ \\
\hline Csn1s1-mGLS-LacZ*-HA & 147 & 92 & $8(4)$ & $12(4)$ \\
\hline CAG-hGLS-LacZ*-Clover-HA & 118 & 81 & $5(2)$ & $11(4)$ \\
\hline
\end{tabular}

Перед получением трансгенных животных было необходимо предварительно оценить активность фермента LaCZ* в клетках млекопитающих, поэтому мы использовали стандартное окрашивание с субстратом X-gal, который похож по структуре на лактозу и гидролизуется $\beta$-галактозидазами с образованием нерастворимого синего пигмента (рис. 4). Через 2 дня после трансфекции плазмидами клетки HEK293 фиксировали в параформальдегиде и инкубировали с X-gal 16 ч. Как видно на рис. 4, при использовании конструкций появился синий пигмент, что говорит о функциональной активности синтезированного гена LacZ* и его вариантов.

Чтобы оценить стабильность LaCZ* в клетках млекопитающих, мы провели Вестерн блоттинг с антителами на НА-таг. Результаты подтверждают правильный синтез белка LacZ* и отсутствие деградации в клетках млекопитающих (рис. 5). Согласно белковому маркеру, бэнды LacZ* лежат в диапазоне 130-180 кDa, что соответствует теоретическому размеру белка (размер белка LacZ* : 1008 аминокислот = 121 кDa; размер самого большого варианта LacZ* + mGLS + Clover + HA-таг: 166 kDa). Таким образом, наличие НА-тага на С-конце белка LacZ* позволит в дальнейшем детектировать его в тканях мышей.
Получение и анализ трансгенных линий мышей Для получения трансгенных мышей нами было выбрано два варианта конструкций: Csn1s1-mGLS-LacZ*-HA и CAG-hGLSLacZ*-Clover-HA (см. рис. 1, г). В первом случае экспрессия гена обеспечивается «молочным» промотором и регуляторными элементами гена а-казеина (Csn1s1) козы и быка, чтобы локализовать активность LaCZ* молочной железой в период лактации. Этот подход был описан в нашей лаборатории ранее (Serova et al., 2012; Burkov et al., 2013). Второй вариант трансгена содержит искусственный CAG-промотор, который должен обеспечивать высокую конститутивную экспрессию LacZ* во всех тканях.

Для пронуклеарных микроинъекций использовали линеаризованные варианты плазмид (см. рис. 1, г). Среднее число родившихся мышат (выживаемость) и доля трансгенных животных для двух линий составили 13 и 30-40\% соответственно (см. таблицу).

ПЦР-генотипирование с праймерами на ген LacZ* показало, что в первой линии с «молочным» промотором родилось 4 F0-фаундеров (рис. 6, a). Для второго варианта конструкции с промотором CAG было также обнаружено 4 трансгенных фаундера (см. рис. 6, б). Для того чтобы опреде- 


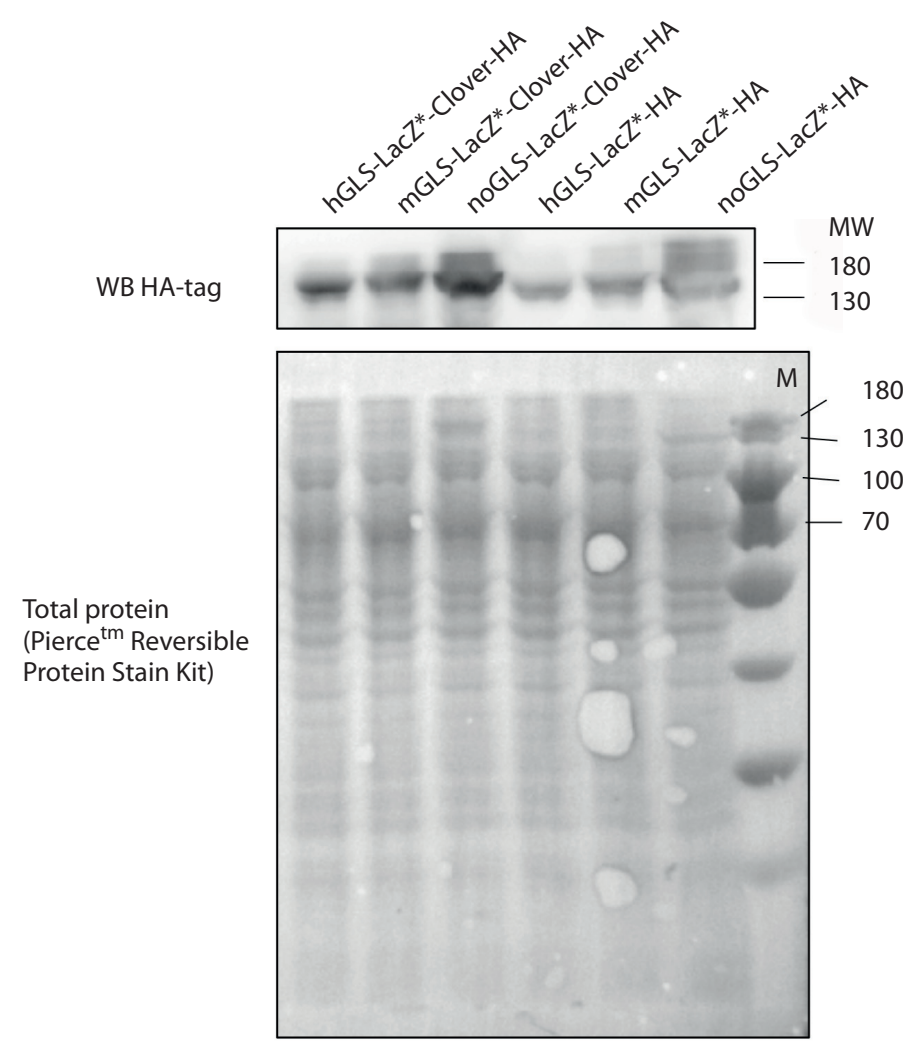

Рис. 5. Вестерн блоттинг с антителами на HA-таг для детекции LacZ*. Тотальный белок из трансфецированных плазмидами клеток разгонялся в денатурирующем 10 \% полиакриламидном геле (SDS-PAGE). Внизу показана PVDF-мембрана после трансфера, обратимо окрашенная на тотальный белок. Вверху фрагмент этой мембраны после окрашивания антителами на НA-таг. MW - молекулярный вес белков в килодальтонах $(\mathrm{kDa})$

$a$

d $202122 \quad 23242526 \quad 2728 \quad 2930 \quad 31$ WT -
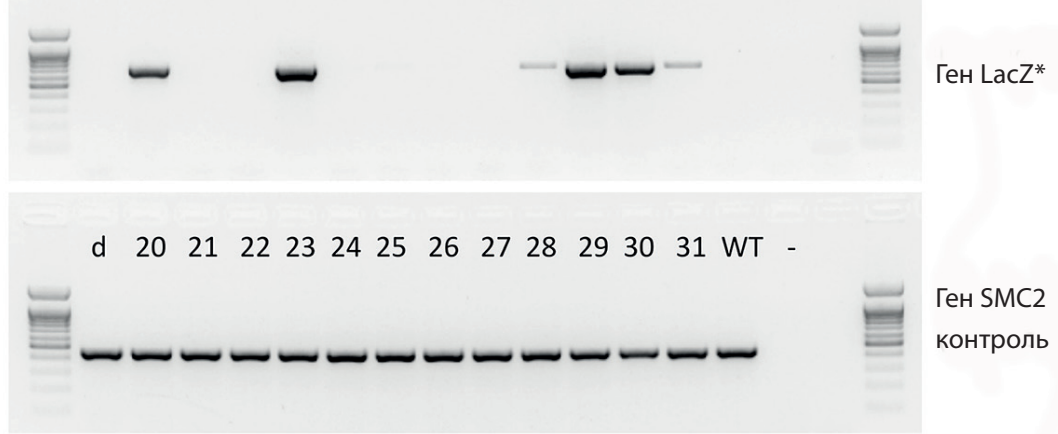

6

3233343536373839404142 WT -

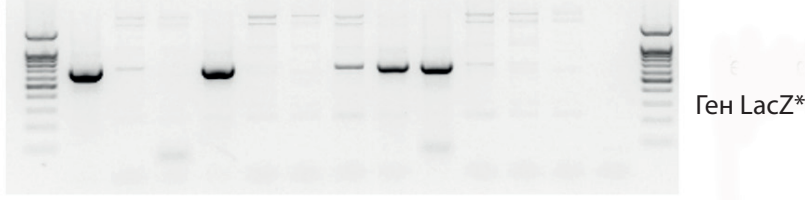

3233343536373839404142 w -

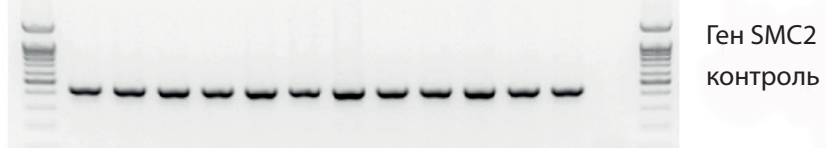

Рис. 6. Генотипирование трансгенных фаундеров: $a$ - конструкция с промотором Csn 1s1. d - мертворожденный потомок. \#20-31 - номера мышей, WT - ДНК дикого типа, (-) - вода. Праймеры на ген LacZ* дают ПЦР-продукт размером 628 п.о. Праймеры на ген SMC2 мыши (контроль качества выделения ДНК) - 410 п.о.; 6 - конструкция с (AG-промотором 




\#20 \#23 \#29 \#30

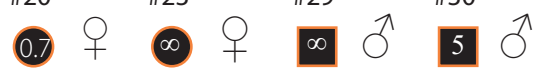
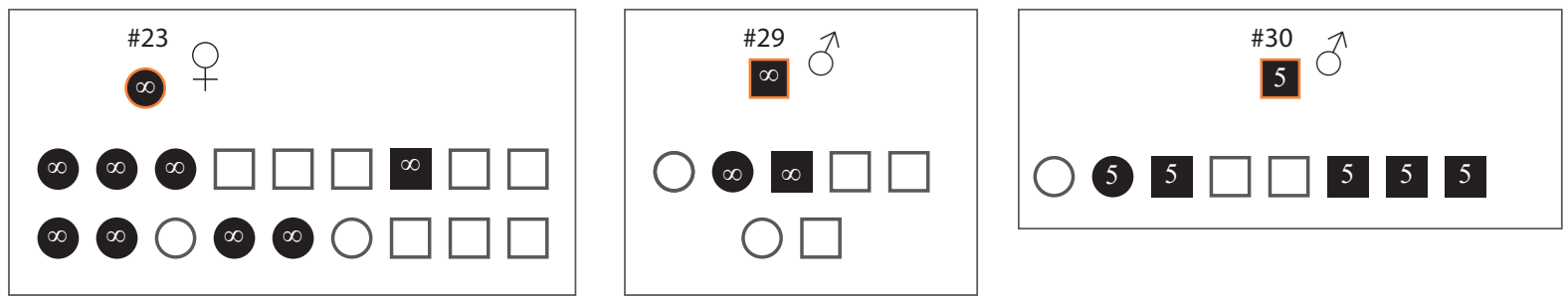

\#32
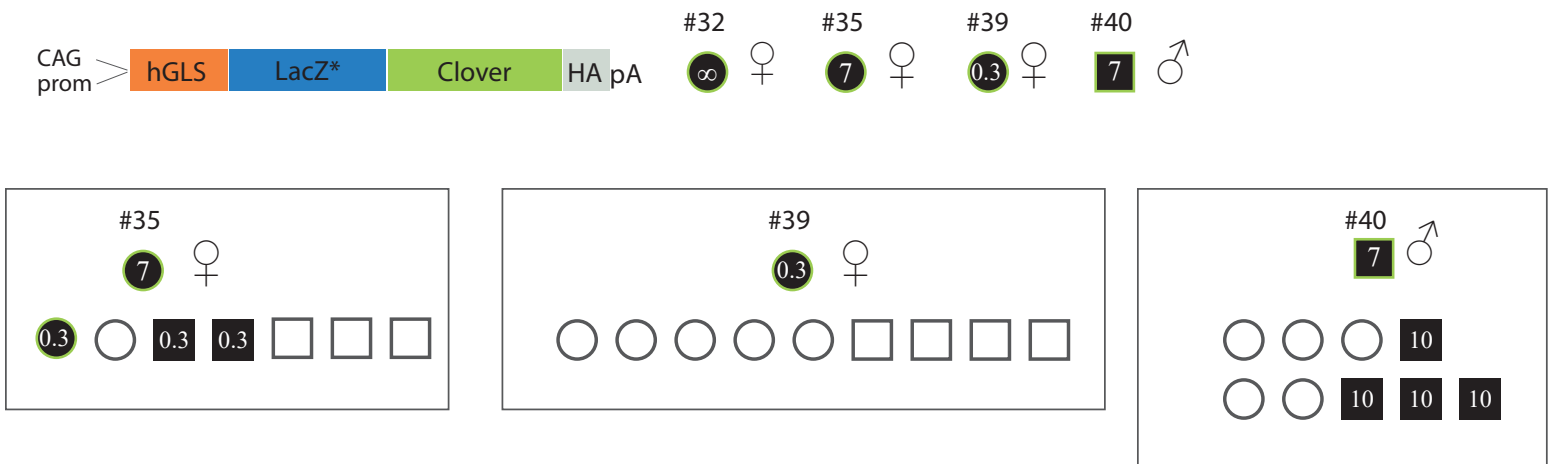

Рис. 7. Общая схема наследования трансгенов в шести линиях. Закрашенные фигуры символизируют трансгенных потомков. Для некоторых фаундеров было получено два помета, которые представлены двумя рядами фигур. Копийность определяли как для F0, так и для F1 животных. $a$ - конструкция с промотором Csn1s1; 6 - конструкция с CAG-промотором

лить примерное число копий трансгена, был проведен анализ копийности методом капельной цифровой ПЦР (ddPCR) (Smirnov et al., 2020) у животных F0 и в дальнейшем у их потомков. Анализ числа копий трансгена (рис. 4П) выявил, что все 8 фаундеров имеют различную копийность, от 0.3 копии трансгена до более чем 50 копий (рис. 7). Число копий ниже 1, как правило, говорит о том, что анализируемое животное является мозаиком, то есть состоит из смеси клеток дикого типа и содержащих трансген. Определение точного значения для многокопийных встроек представляет технические сложности в ddPCR, так как требует сильного разбавления ДНК и подбора условия для референсного гена Emid1. По этой причине мы не ставили себе целью точное определение копийности в многокопийных линиях. Для них копийность обозначена значком $\infty$ (> 50 копий). Как мы и ожидали, животные со слабыми бэндами (\#28, 31, 33, 38) имели очень низкую копийность $(<0.01)$, поэтому не рассматривались для скрещиваний.

Для получения потомства F1 трансгенные фаундеры скрещивались с животными линии C57BL/6. Самка и самец F0 c молочным промотором \#23 и 30 передавали трансген $\sim 50 \%$ потомков, что говорит о нормальном наследовании трансгена (рис. 7). В линии \#29 размер двух пометов был меньше ожидаемого, это может служить индикато- ром инсерционного мутагенеза в линии \#29 и требует дополнительного изучения. Среди скрещиваний FO с CAGпромотором ни одно не дало нормальных F1-самок для анализа экспрессии LacZ* в молочной железе. Так, F0 самка \#35 не передавала трансген своим потомкам (в этой линии наблюдается слабый сигнал при ПЦР-генотипировании, но это может быть обломок трансгена); F0 самка \#39 имела серьезный мозаицизм (только 0.3 копии трансгена) и также не передавала трансген потомкам; F0 самец \#40 передавал трансген только самцам, что говорит об интеграции конструкции в Ү-хромосому.

В настоящий момент ведутся скрещивания двух последних фаундеров (\#20 и 32) для анализа наследования и экспрессии LacZ*.

Самки из линий \#23, 30 и 35 были выбраны для анализа органов и сбора молока. Мы также собрали органы от самцов линии \#40. Анализ экспрессии гена LacZ* методом ОТ-ПЦР показал невысокий уровень экспрессии LacZ* В молочной железе (рис. 8, a) и отсутствие экспрессии в органах одного из F1 самцов линии \#40. (Это может быть вызвано интеграцией в транскрипционно неактивный сайт на Y-хромосоме.) Анализ тех же образцов кДНК капельной цифровой ПЦР (ddPCR) показал относительно низкий уровень экспрессии в молочной железе - примерно 0.01 \% от 




Pис. 8. Предварительный анализ экспрессии трансгена в тканях мышей: $a$ - ОТ-ПЦР с праймерами на трансген и контрольный ген (Rpl4). Обозначения: Fibr+ - положительный контроль (трансфецированные плазмидой фибробласты мыши); МЖ - молочные железы из разных линий. Последние четыре образца - органы $\mathrm{F}_{1}$ самца линии \#40 (сердце, легкие, почка, селезенка). RT - контроль на контаминацию ДНК (обратная транскрипция без добавления фермента); б - капельная цифровая ПЦР для анализа экспрессии. Образцы кДНК были взяты в том же порядке, что и в ОТ-ПЦР

Rpl4 (см. рис. 8, 6 и 5П). Нами было также собрано молоко от трансгенных самок - \#23, 30, 35 (рис. 6П). Оно может быть использовано для предварительного анализа эффекта LacZ на содержание лактозы и отработки методов изучения углеводного состава молока.

\section{Обсуждение}

В молочной промышленности используется большое количество бактериальных $\beta$-галактозидаз, многие из них запатентованы (Vera et al., 2016; Botvynko et al., 2019). Сейчас идет активный поиск новых ферментов, которые имели бы улучшенные характеристики и высокую трансгалактозилазную активность для получения ГOC (Liu et al., 2017; Kittibunchakul et al., 2019; Qin et al., 2019). Для нашего проекта мы остановили свой выбор на гене LacZ* из бактерии Lactobacillus delbrueckii subsp. bulgaricus DSM 20081 (Nguyen et al., 2012). Эта бактерия метаболизирует лактозу в качестве единственного источника энергии, и фермент LacZ* имеет подходящие характеристики для экспрессии в молочной железе. Фермент, выбранный нами для проекта, имеет более высокую эффективность конверсии лактозы (30 \% глюкозы, 12 \% галактозы, 10 \% лактозы, 48 \% ГОС), чем более ранние аналоги (Vera et al., 2016).

Нам известны два исследования, в которых предпринята попытка создать животных с безлактозным молоком. В работе (Stinnakre et al., 1994) были получены мыши с нокаутом по гену а-лактальбумина (кофактора лактоз-синтазы $\beta 4 G a l-T 1)$, что привело к полному отсутствию лактозы в молоке. (Нокауты по гену самой лактоз-синтазы $\beta 4 G a l-T 1$ сублетальны и вызывают раннюю смерть, так как, помимо синтеза лактозы, B4Gal-T1 участвует в N-гликозилировании белков (Asano et al., 1997).) Интересно, что, хотя основные компоненты моло- 
ка не были затронуты, лактация практически прекратилась из-за высокой вязкости капель внутри клеток молочного эпителия (Stinnakre et al., 1994), вызванной нарушением осмотического баланса. Авторы второй работы учли эти данные, выбрав подход с оверэкспрессией гена лактазы крысы, который в норме активен в эпителии кишечника (Jost et al., 1999). Они создали линию мышей с экспрессией лактазы под промотором молочного гена и показали, что это снижает содержание лактазы в молоке на 50-85 \%. Одной из обнаруженных ими проблем была реабсорбция глюкозы обратно в молочную железу, поэтому углеводный состав полученного молока был хуже ожидаемого. Плотность молока также отличалась от нормальной (Jost et al., 1999).

Таким образом, несбалансированное снижение концентрации лактозы в молоке приводит к повышению вязкости и уменьшению объема молока, а также к ухудшению его пищевой ценности. Эта проблема пока не решена, поэтому успешных глобальных проектов по созданию «безлактозных» животных еще нет. На наш взгляд, оптимальный подход по созданию безлактозного молока заключается в модификации лактоз-синтазы $\beta 4 G a l-T 1$ для того, чтобы она создавала альтернативные сахара (Ramakrishnan, Qasba, 2002). В этом случае можно будет соединить нокаут по гену a-лактальбумина и встройку модифицированной $\beta 4 G a l-T 1$ в геном. К сожалению, исследования по молекулярному моделированию субстрат-специфичности лактазы $\beta 4 \mathrm{Gal-T1}$ пока еще только начинаются (Qasba et al., 2008; MacArthur, Chen, 2016).

Эксперименты по модификациям состава молока можно проводить на специальных культурах клеток молочной железы (Tsugami et al., 2020) или на органоидах молочной железы (Sumbal et al., 2020). Исходя из нашего опыта создание трансгенных мышей и анализ лактации с отработанным протоколом занимает не так много времени, но гораздо информативней. В ходе работы мы планировали предварительно протестировать различные аспекты этого подхода, включая и два варианта дизайна трансгена.

Во-первых, мы хотели сравнить альтернативные промоторы: Csn1s1 и CAG. Конструкция с «молочным» промотором Csn1s1, изученным ранее в нашей лаборатории (Serova et al., 2012; Burkov et al., 2013), включает в себя промотор гена альфа-S1-казеина козы (Csn1s1), и нетранслируемые регуляторные элементы (UTR), фланкирующие трансген: интрон 1 от Csn1s1 козы и интрон 18 от Csn1s1 быка (розовые прямоугольники на рис. 1, 2). Промотор должен обеспечивать экспрессию LacZ* строго во время лактации в молочной железе, однако его экспрессия может быть не такой высокой, как у промотора CAG. Промотор CAG является сильным промотором (Chen et al., 2011) и должен гарантировать высокий уровень экспрессии трансгена, но в то же время повсеместная экспрессия фермента LacZ* может быть токсичной для организма. Ген LacZ E. coli часто используется в биологии для получения трансгенных животных и не обладает токсичностью, но выбранный нами вариант LacZ* не гомологичен классическому $\mathrm{LaCZ}$, имеет дополнительные каталитические домены и ранее не тестировался на мышах. K сожалению, в нашем случае трансгенные линии с CAG не передавали трансген самкам, из-за чего анализ молока ока- зался невозможным. Единственная линия, в которой определялась передача трансгена потомкам (\#40), не показала экспрессии в органах самца (см. рис. 8), вероятно, в связи с интеграцией трансгена в Ү-хромосому.

Во-вторых, мы планировали сравнить два сигнала локализации - hGLS и mGLS. Оба сигнала локализации показывали схожий паттерн локализации в клетках человека НЕК293 и фибробластах мыши (см. рис. 2). Мы решили выбрать оба варианта, так как гистохимический анализ молочных желез с антителами на НА-таг (см. рис. 3) и различные компартменты (цис- и транс-отдел АГ, ЭПР) поможет более точно выявить эффективность локализации в АГ для двух вариантов GLS. Для дальнейших экспериментов будет интересно сравнить и то, как отсутствие GLS скажется на активности LacZ* , вариант noGLS (см. рис. 1, в).

Наконец, при дизайне конструкций LacZ* мы запланировали возможность удаления из плазмид гена Clover (см. рис. 1,8$)$, так как его присутствие может влиять на каталитическую активность LacZ*. Однако также известны случаи, когда наличие дополнительных доменов помогает увеличивать стабильность и экспрессию чужеродного белка за счет улучшения фолдинга. Данные Вестерн блота (см. рис. 5), на которых видно, что укороченные версии конструкций LacZ* дают более слабый сигнал, также могут указывать на стабилизирующую роль Clover в составе LacZ*.

Анализ перечисленных параметров трансгенных линий поможет отработать методику для получения более сложных вариантов модификаций молока. К примеру, в настоящий момент мы рассматриваем альтернативный подход, который заключается в замене активности собственной лактоз-синтазы $\beta 4 G a l-T 1$ мыши на другой фермент из класса гликозилтрансфераз, который бы синтезировал дисахарид трегалозу, наиболее близкий лактозе по свойствам углевод (Elbein et al., 2003). Трегалоза распространена в природе, ее синтез описан у дрожжей, членистоногих и грибов, но отсутствует у позвоночных (Argüelles, 2014; Hibshman et al., 2017). Мы проанализировали возможность замены $\beta 4 \mathrm{Gal}-\mathrm{T} 1$ мыши на трегалоз-синтазу из других организмов, например E. coli (Guo et al., 2000), нематоды (Hibshman et al., 2017) или грибов-базидиомицетов (Saito et al., 1998). Возможность биосинтеза трегалозы была ранее показана в клетках млекопитающих (Guo et al., 2000), но возникает много вопросов, связанных с компартментализацией в клетках молочной железы, так как синтез молока идет внутри аппарата Гольджи, в то время как необходимые для синтеза трегалозы компоненты (трегалоз-6-фосфат или a-D-глюкоз-1-фосфат) находятся в цитоплазме. Совместив синтез трегалозы в молоке с нокаутом по гену лактальбумина, можно было бы повлиять на состав молока, заменив лактозу на трегалозу и сохранив основные свойства молока.

\section{Заключение}

Мышиные трансгенные модели удобно использовать как тест-систему для проверки различных $\beta$-галактозидаз или других ферментов для синтеза широкого спектра галактоолигосахаридов. Мышиное молоко похоже по содержанию лактозы на молоко сельскохозяйственных животных (2-5 \% 
веса), поэтому выбранные ферменты можно будет применять и для генетических модификаций в сельском хозяйстве.

С практической точки зрения выбор оптимальных сигналов локализации и промоторов будет важен для дальнейших биоинженерных работ по изменению свойств молока. Молоко, в котором лактоза заменена на альтернативный сахар (в нашем случае ГОС), сочетает в себе сразу несколько востребованных качеств: отсутствие лактозы и необычный вкус, а также не требует дополнительной переработки. По этой причине проекты, направленные на поиск генетических путей для модификации лактозного синтеза, очень актуальны, так как в случае функциональности такого подхода можно будет использовать целый спектр доступных гликозилтрансфераз (McArthur, Chen, 2016) для синтеза новых вариантов сахаров непосредственно в молочной железе.

\section{Список литературы / References}

Argüelles J.C. Why can't vertebrates synthesize trehalose? J. Mol. Evol. 2014;79(3-4):111-116. DOI 10.1007/s00239-014-9645-9.

Arribas J.C., Herrero A.G., Martín-Lomas M., Cañada F.J., He S., Withers S.G. Differential mechanism-based labeling and unequivocal activity assignment of the two active sites of intestinal lactase/phlorizin hydrolase. Eur. J. Biochem. 2000;267(24):6996-7005. DOI 10.1046/j.14321327.2000.01784.x.

Asano M., Furukawa K., Kido M., Matsumoto S., Umesaki Y., Kochibe N. Iwakura Y. Growth retardation and early death of beta-1,4-galactosyltransferase knockout mice with augmented proliferation and abnormal differentiation of epithelial cells. EMBO J. 1997;16(8):1850-1857. DOI 10.1093/emboj/16.8.1850.

Botvynko A., Bednářová A., Henke S., Shakhno N., Čurda L. Production of galactooligosaccharides using various combinations of the commercial $\beta$-galactosidases. Biochem. Biophys. Res. Commun. 2019;517(4):762-766. DOI 10.1016/j.bbrc.2019.08.001.

Burkov I.A., Serova I.A., Battulin N.R., Smirnov A.V., Babkin I.V., Andreeva L.E., Dvoryanchikov G.A., Serov O.L. Expression of the human granulocyte-macrophage colony stimulating factor (hGM-CSF) gene under control of the $5^{\prime}$-regulatory sequence of the goat alpha-S1-casein gene with and without a MAR element in transgenic mice. Transgenic Res. 2013;22(5):949-964. DOI 10.1007/s11248-0139697-4.

Chen C.M., Krohn J., Bhattacharya S., Davies B. A comparison of exogenous promoter activity at the ROSA26 locus using a ФiC31 integrase mediated cassette exchange approach in mouse ES cells. PLoS One. 2011;6(8):e23376. DOI 10.1371/journal.pone.0023376.

Cooper C.A., Maga E.A., Murray J.D. Production of human lactoferrin and lysozyme in the milk of transgenic dairy animals: past, present, and future. Transgenic Res. 2015;24(4):605-614. DOI 10.1007/s11248-0159885-5.

Elbein A.D., Pan Y.T., Pastuszak I., Carroll D. New insights on trehalose: a multifunctional molecule. Glycobiology. 2003;13(4):17R-27R. DOI 10.1093/glycob/cwg047.

Fang L., Ahn J.K., Wodziak D., Sibley E. The human lactase persistenceassociated SNP $-13910^{*} T$ enables in vivo functional persistence of lactase promoter-reporter transgene expression. Hum. Genet. 2012;131(7):1153-1159. DOI 10.1007/s00439-012-1140-z.

Fassio F., Facioni M.S., Guagnini F. Lactose maldigestion, malabsorption, and intolerance: a comprehensive review with a focus on current management and future perspectives. Nutrients. 2018;10(11):1599. DOI 10.3390/nu10111599.

Gabius H.J. The sugar code: Why glycans are so important. Biosystems. 2018;164:102-111. DOI 10.1016/j.biosystems.2017.07.003.

Goedhart J., von Stetten D., Noirclerc-Savoye M., Lelimousin M., Joosen L. Hink M.A., van Weeren L., Gadella T.W. Jr., Royant A. Structure-guided evolution of cyan fluorescent proteins towards a quantum yield of 93\%. Nat. Commun. 2012;3:751. DOI 10.1038/ncomms1738.

Gulati K., Poluri K.M. Mechanistic and therapeutic overview of glycosaminoglycans: the unsung heroes of biomolecular signaling. Glycoconj J. 2016;33(1):1-17. DOI 10.1007/s10719-015-9642-2.
Guo N., Puhlev I., Brown D.R., Mansbridge J., Levine F. Trehalose expression confers desiccation tolerance on human cells. Nat. Biotechnol. 2000;18(2):168-171. DOI 10.1038/72616.

Gurtan A.M., Lu V., Bhutkar A., Sharp P.A. In vivo structure-function analysis of human Dicer reveals directional processing of precursor miRNAs. RNA. 2012;18(6):1116-1122. DOI 10.1261/rna.032680.112.

Hibshman J.D., Doan A.E., Moore B.T., Kaplan R.E., Hung A., Webster A.K., Bhatt D.P., Chitrakar R., Hirschey M.D., Baugh L.R. daf-16/FoxO promotes gluconeogenesis and trehalose synthesis during starvation to support survival. Elife. 2017;6:e30057. DOI 10.7554/eLife.30057.

Ingram C.J., Mulcare C.A., Itan Y., Thomas M.G., Swallow D.M. Lactose digestion and the evolutionary genetics of lactase persistence. Hum. Genet. 2009;124(6):579-591. DOI 10.1007/s00439-008-0593-6.

Jost B., Vilotte J.L., Duluc I., Rodeau J.L., Freund J.N. Production of low-lactose milk by ectopic expression of intestinal lactase in the mouse mammary gland. Nat. Biotechnol. 1999;17(2):160-164. DOI 10.1038/6158.

Kalds P., Zhou S., Cai B., Liu J., Wang Y., Petersen B., Sonstegard T., Wang X., Chen Y. Sheep and Goat Genome Engineering: From Random Transgenesis to the CRISPR Era. Front Genet. 2019;10:750. DOI 10.3389/fgene.2019.00750.

Kittibunchakul S., Pham M.L., Tran A.M., Nguyen T.H. $\beta$-Galactosidase from lactobacillus helveticus dsm 20075: biochemical characterization and recombinant expression for applications in dairy industry. Int. J. Mol. Sci. 2019;20(4):947. DOI 10.3390/ijms20040947.

Laible G., Smolenski G., Wheeler T., Brophy B. Increased gene dosage for $\beta$ - and $\mathrm{k}$-casein in transgenic cattle improves milk composition through complex effects. Sci. Rep. 2016;6:37607. DOI 10.1038/ srep37607.

LiuY.,ChenZ.,JiangZ., YanQ.,YangS.Biochemicalcharacterization ofanovel $\beta$-galactosidase from Paenibacillus barengoltzii suitable for lactose hydrolysis and galactooligosaccharides synthesis. Int. J. Biol. Macromol. 2017;104(Pt A):1055-1063. DOI 10.1016/j.ijbiomac.2017.06.073.

McArthur J.B., Chen X. Glycosyltransferase engineering for carbohydrate synthesis. Biochem. Soc. Trans. 2016;44(1):129-142. DOI 10.1042/ BST20150200.

Mihov D., Spiess M. Glycosaminoglycans: Sorting determinants in intracellular protein traffic. Int. J. Biochem. Cell Biol. 2015;68:87-91. DOI 10.1016/j.biocel.2015.08.019.

Neville M.C. Introduction: alpha-lactalbumin, a multifunctional protein that specifies lactose synthesis in the Golgi. J. Mammary Gland Biol. Neoplasia. 2009;14(3):211-212. DOI 10.1007/s10911-009-9149-1.

Nguyen T.T., Nguyen H.A., Arreola S.L., Mlynek G., Djinović-Carugo K., Mathiesen G., Nguyen T.H., Haltrich D. Homodimeric $\beta$-galactosidase from Lactobacillus delbrueckii subsp. bulgaricus DSM 20081: expression in Lactobacillus plantarum and biochemical characterization. J. Agric. Food Chem. 2012;60(7):1713-1721. DOI 10.1021/jf203909e.

Qasba P.K., Ramakrishnan B., Boeggeman E. Structure and function of beta -1,4-galactosyltransferase. Curr. Drug Targets. 2008;9(4):292-309. DOI 10.2174/138945008783954943.

Qin Z., Li S., Huang X., Kong W., Yang X., Zhang S., Cao L., Liu Y. Improving galactooligosaccharide synthesis efficiency of $\beta$-galactosidase bgal $1-3$ by reshaping the active site with an intelligent hydrophobic amino acid scanning. J. Agric. Food Chem. 2019;67(40): 11158-11166. DOI 10.1021/acs.jafc.9b04774.

Ramakrishnan B., Qasba P.K. Structure-based design of beta 1,4-galactosyltransferase I (beta 4Gal-T1) with equally efficient $\mathrm{N}$-acetylgalactosaminyltransferase activity: point mutation broadens beta 4Gal-T1 donor specificity. J. Biol. Chem. 2002;277(23):20833-20839. DOI 10.1074/jbc.M111183200.

Saito K., Yamazaki H., Ohnishi Y., Fujimoto S., Takahashi E., Horinouchi S. Production of trehalose synthase from a basidiomycete, Grifola frondosa, in Escherichia coli. Appl. Microbiol. Biotechnol. 1998;50(2):193198. DOI 10.1007/s002530051276.

Saqib S., Akram A., Halim S.A., Tassaduq R. Sources of $\beta$-galactosidase and its applications in food industry. 3 Biotech. 2017;7(1):79. DOI 10.1007/s13205-017-0645-5.

Ségurel L., Bon C. On the Evolution of Lactase Persistence in Humans. Annu. Rev. Genomics Hum. Genet. 2017;18:297-319. DOI 10.1146/ annurev-genom-091416-035340.

Serova I.A., Dvoryanchikov G.A., Andreeva L.E., Burkov I.A., Dias L.P., Battulin N.R., Smirnov A.V., Serov O.L. A 3,387 bp 5'-flanking sequence 
of the goat alpha-S1-casein gene provides correct tissue-specific expression of human granulocyte colony-stimulating factor (hGCSF) in the mammary gland of transgenic mice. Transgenic Res. 2012;21(3):485-498. DOI 10.1007/s11248-011-9547-1.

Shepelev M.V., Kalinichenko S.V., Deykin A.V., Korobko I.V. Production of Recombinant Proteins in the Milk of Transgenic Animals: Current State and Prospects. Acta Naturae. 2018;10(3):40-47.

Smirnov A., Fishman V., Yunusova A., Korablev A., Serova I., Skryabin B.V., Rozhdestvensky T.S., Battulin N. DNA barcoding reveals that injected transgenes are predominantly processed by homologous recombination in mouse zygote. Nucleic Acids Res. 2020;48(2):719-735. DOI 10.1093/nar/gkz1085.

Stinnakre M.G., Vilotte J.L., Soulier S., Mercier J.C. Creation and phenotypic analysis of alpha-lactalbumin-deficient mice. Proc. Natl. Acad. Sci. USA. 1994;91(14):6544-6548. DOI 10.1073/pnas.91.14.6544.

Sumbal J., Chiche A., Charifou E., Koledova Z., Li H. Primary mammary organoid model of lactation and involution. Front. Cell Dev. Biol. 2020;8:68. DOI 10.3389/fcell.2020.00068.
Tannous A., Pisoni G.B., Hebert D.N., Molinari M. N-linked sugar-regulated protein folding and quality control in the ER. Semin. Cell Dev. Biol. 2015;41:79-89. DOI 10.1016/j.semcdb.2014.12.001.

Tsugami Y., Suzuki N., Kawahara M., Suzuki T., Nishimura T., Kobayashi K. Establishment of an in vitro culture model to study milk production and the blood-milk barrier with bovine mammary epithelial cells. Anim. Sci. J. 2020;91(1):e13355. DOI 10.1111/asj.13355.

Vera C., Córdova A., Aburto C., Guerrero C., Suárez S., Illanes A. Synthesis and purification of galacto-oligosaccharides: state of the art. World J. Microbiol. Biotechnol. 2016:32(12):197. DOI 10.1007/s11274016-2159-4.

Wang Y., Sheng Z., Wang Y., Li Q., Gao Y., Wang Y., Dai Y., Liu G., Zhao Y., Li N. Transgenic mouse milk expressing human bile salt-stimulated lipase improves the survival and growth status of premature mice. Mol. Biotechnol. 2015;57(3):287-297. DOI 10.1007/s12033-014-9822-5.

Xiao Y., Chen Q., Guang C., Zhang W., Mu W. An overview on biological production of functional lactose derivatives. Appl. Microbiol. Biotechnol. 2019;103(9):3683-3691. DOI 10.1007/s00253-019-09755-6.

Конфликт интересов. Авторы заявляют об отсутствии конфликта интересов.

Поступила в редакцию 03.11.2021. После доработки 19.11.2021. Принята к публикации 22.11.2021. 


\section{Приложение}


Рис. 1П. Флуоресцентный анализ клеток HEK293 (а) и первичных фибробластов мыши (б), трансфецированных плазмидами mGLS-LacZ*-Clover-HA или noGLS-LacZ*-Clover-HA. Контрольная плазмида - hGLS-mCherry-HA 
Плазмидная трансфекция HEK293: LacZ-Clover без сигнала локализации
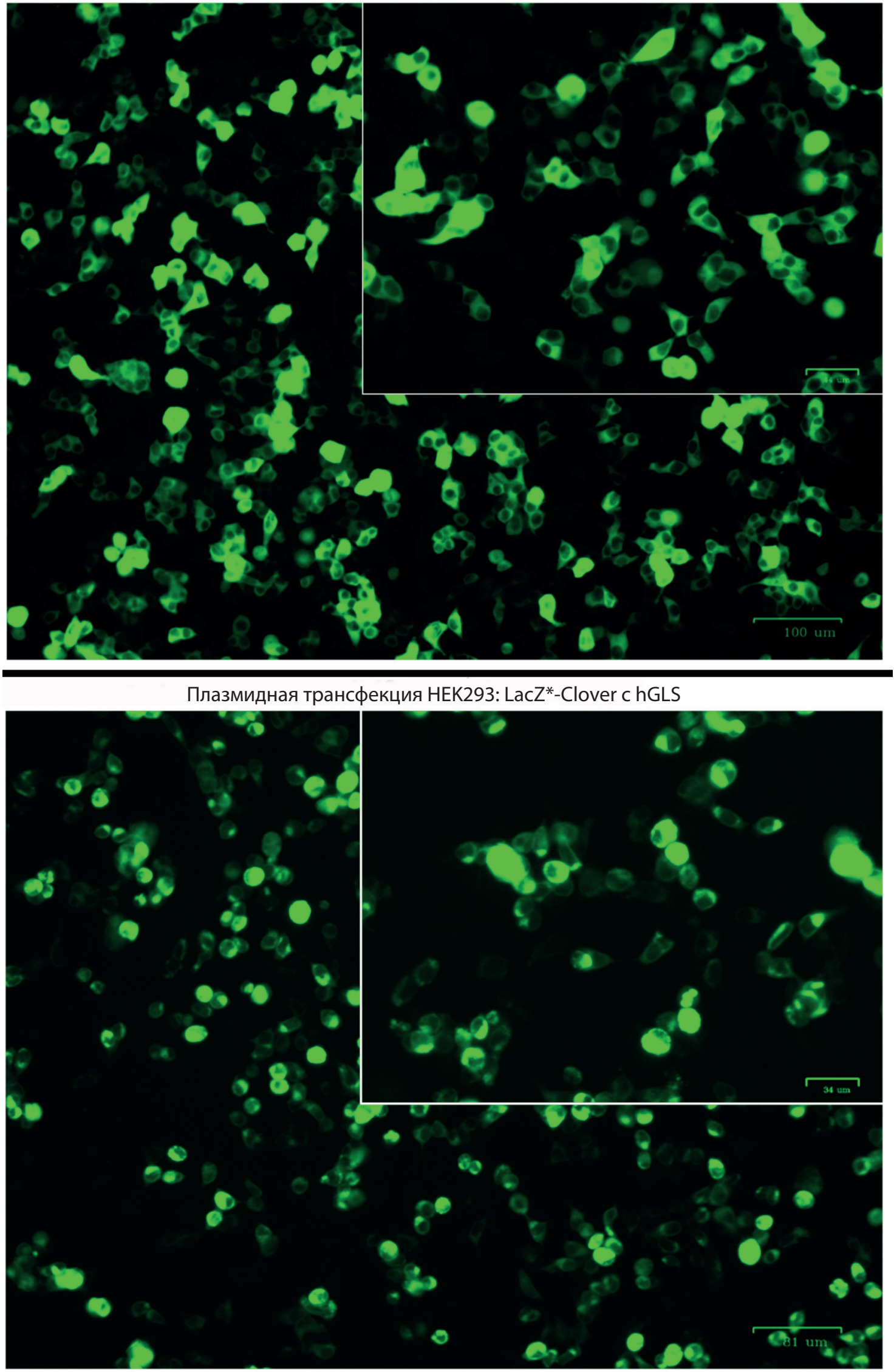

Рис. 2П. Общий вид популяции клеток HEK293 после трансфекции плазмидами LacZ с сигналом локализации или без него 
Плазмидная трансфекция фибробластов
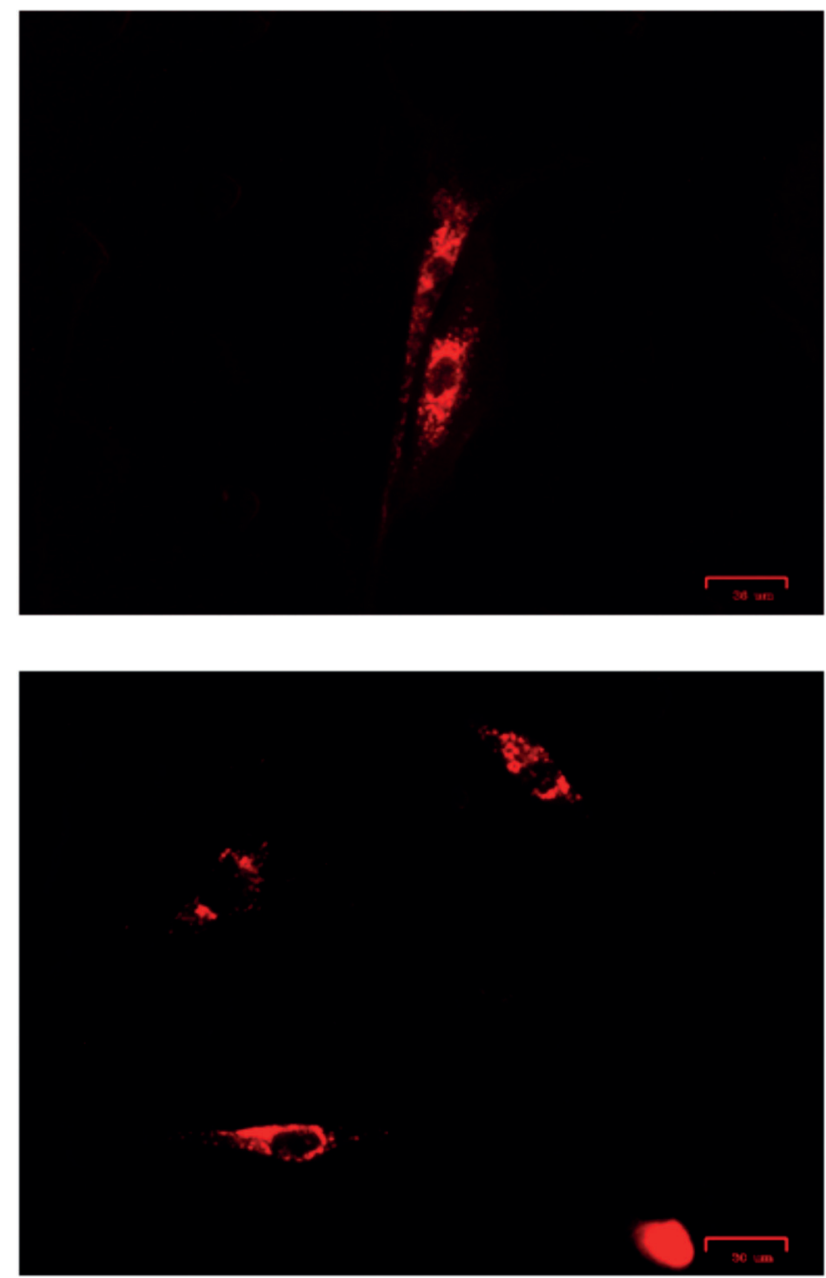

Рис. 3П. Первичные фибробласты мыши после трансфекции плазмидой mCherry с сигналом локализации hGLS
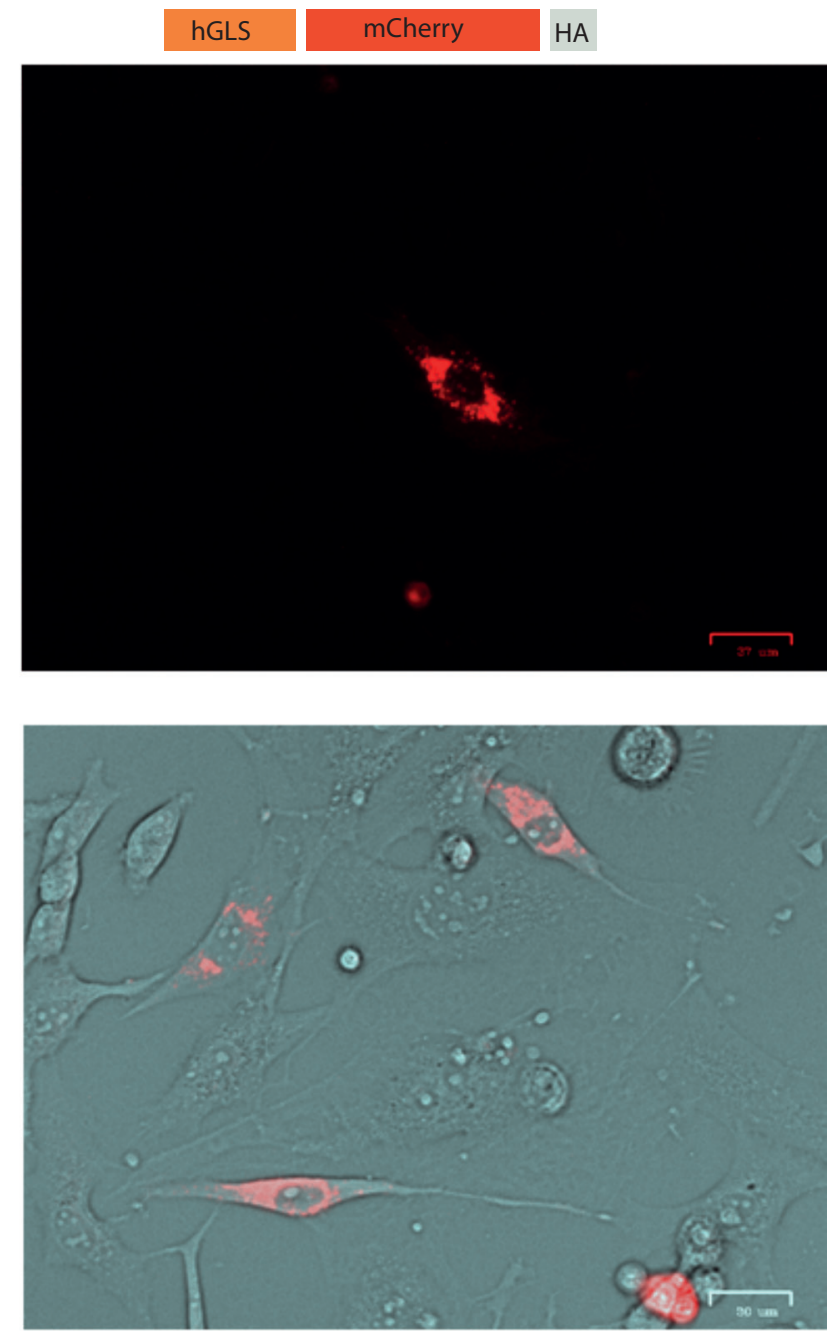


\section{Температура отжига $68>>>0^{\circ} \mathrm{C}$}

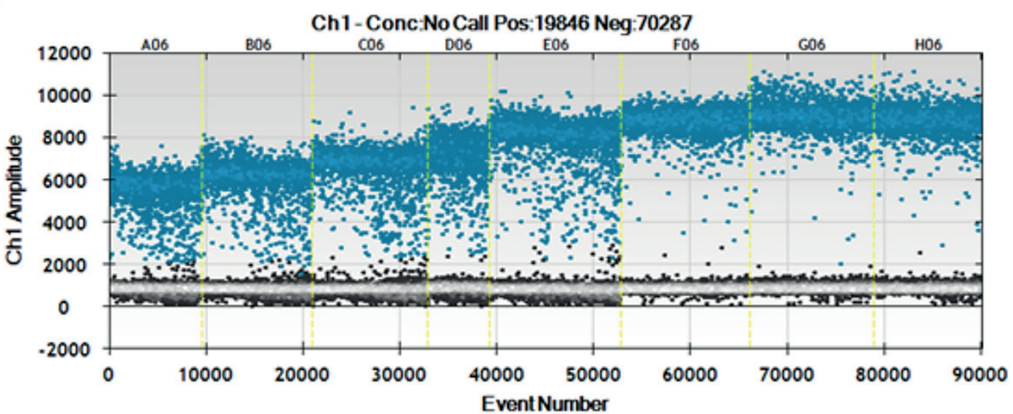

Зонд на ген Emid1

(контроль) (FAM)

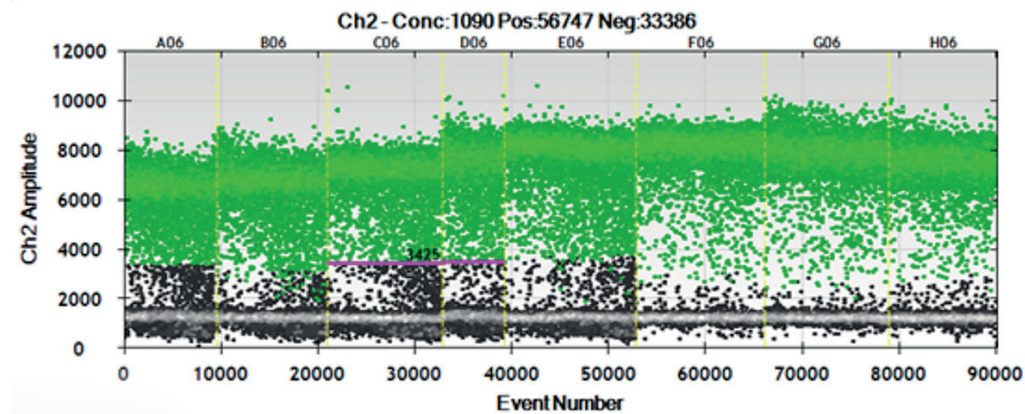

Зонд на ген LacZ (HEX)

Рис. 4П. Градиент для капельной цифровой ПЦР для анализа копийности в линии мышей с числом копий $=5$

Температура отжига $68>>50^{\circ} \mathrm{C}$

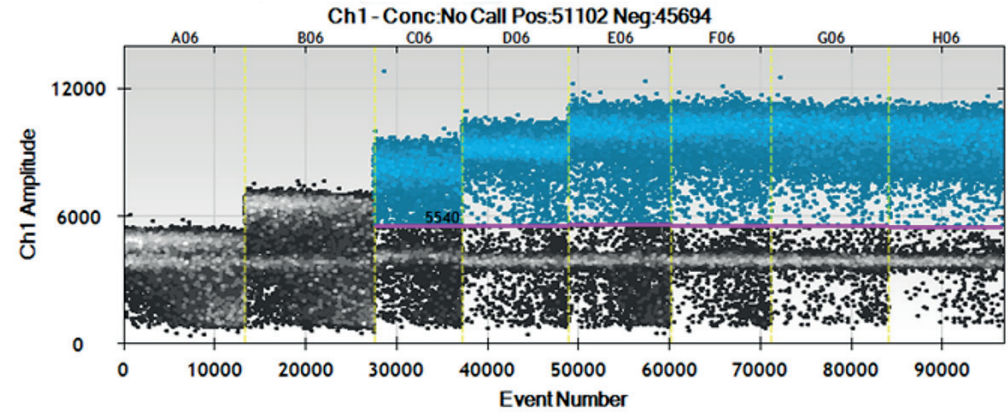

Зонд на ген Rpl14 (контроль) (FAM)

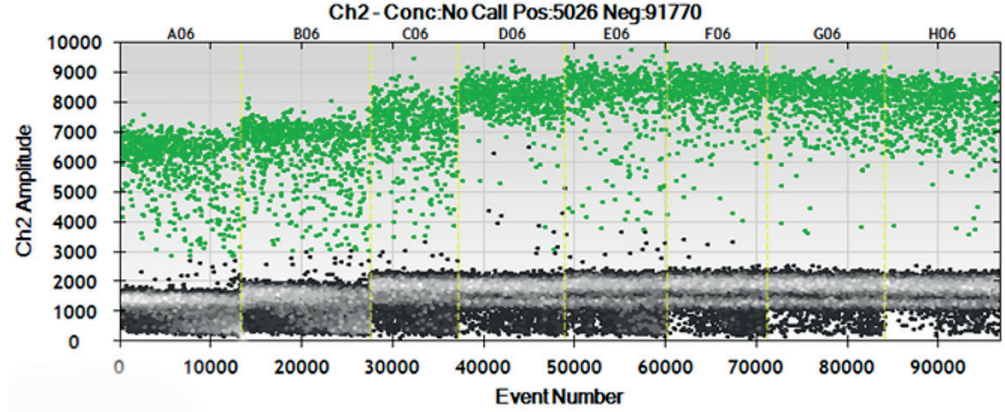

Зонд на ген LacZ* (HEX)

Рис. 5П. Градиент для капельной цифровой ПЦР для анализа экспрессии гена LacZ*. кДHK получена из фибробластов мыши, трансфецированных плазмидой hGLS-LacZ-Clover-HA 


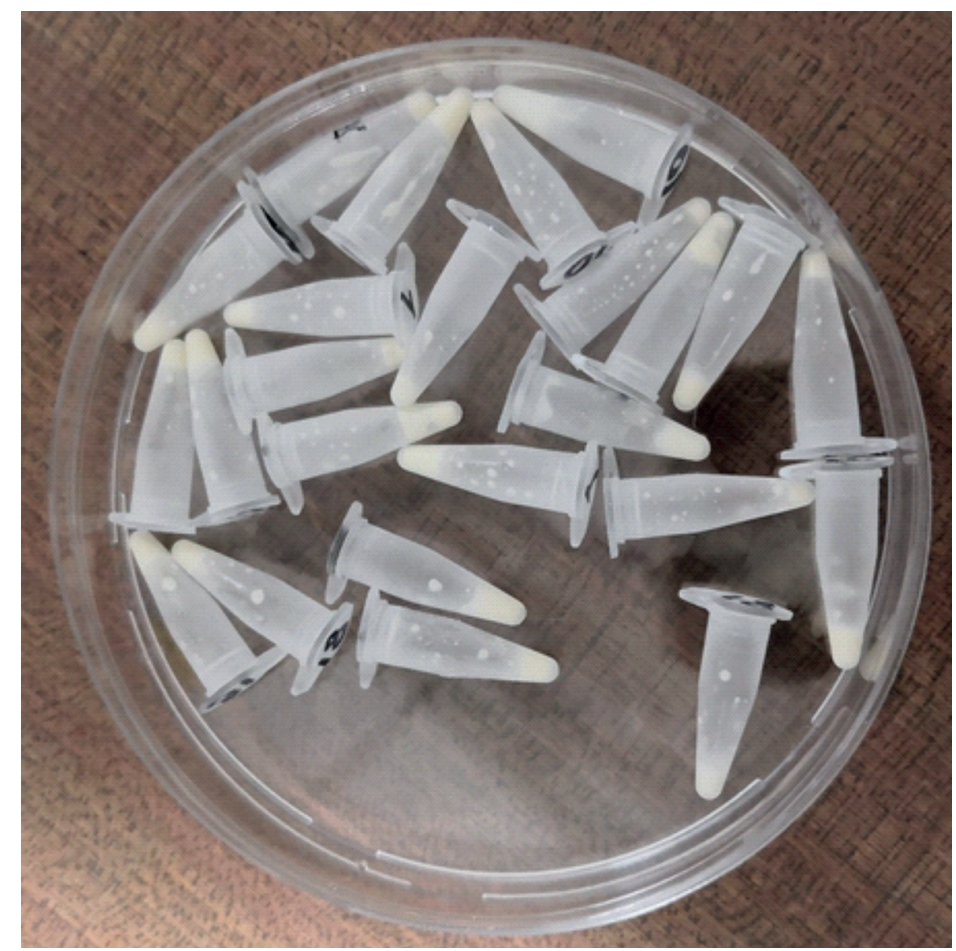

Рис. 6П. Молоко, собранное от трансгенных самок линий \#23, 30, 35 